\title{
EKOLOGIA DZIEDZICTWA. PRZYCZYNEK DO TEMATU
}

\section{Abstract \\ Ecology of Heritage. Introduction to the Research Problem}

In this article the author has tried to propose a new approach to cultural heritage from the perspective of ecological concepts. The author, based on a rich literature and conclusions of her previous research, is trying to understand the phenomenon of heritage anew. In a special way within the text were exposed these aspects of heritage and its environment, which according to the author constitute the uniqueness of this resource for building a sustainable local development.

Keywords: ecology of heritage, heritage management, cultural heritage, heritage stakeholders

\section{Streszczenie}

W niniejszym artykule została podjęta próba zaproponowania nowego spojrzenia na dziedzictwo kulturowe z perspektywy koncepcji ekologicznych. Na podstawie bogatej literatury przedmiotu oraz posiłkując się wnioskami z dotychczasowych badań własnych, autorka stara się na nowo zrozumieć fenomen dziedzictwa. W sposób szczególny zostały w tekście wyeksponowane te aspekty dziedzictwa oraz jego otoczenia, które zdaniem autorki stanowią o wyjątkowości tego zasobu dla budowania zrównoważonego rozwoju lokalnego.

Słowa kluczowe: ekologia dziedzictwa, zarządzanie dziedzictwem, dziedzictwo kulturowe, interesariusze dziedzictwa

\section{Wprowadzenie}

Teoretycy dziedzictwa coraz częściej w swoich rozważaniach powołują się na konieczność przyjęcia zintegrowanego podejścia do zagadnienia dziedzictwa kulturowego, uwzględniając zarówno społeczne, jak i ekonomiczne oddziaływanie tychże zasobów na rozwój. Takie ujęcie można odnaleźć m.in. w pracach Gregory'ego Ashwortha, Petera Howarda, czy na gruncie polskim w tekstach Moniki Murzyn-Kupisz oraz Jacka Purchli [Howard, 2003; Murzyn-Kupisz, 
2010; Purchla, 2014; Ashworth, Graham, Tunbridge, 2007]. Podkreślana jest również wielość interesariuszy zaangażowanych $\mathrm{w}$ procesy tworzenia i zarządzania zasobami dziedzictwa kulturowego, co czyni m.in. Łukasz Gaweł [Gaweł, 2012]. W raporcie Dziedzictwo kulturowe w oczach Polaków, opracowanym na zlecenie Narodowego Instytutu Dziedzictwa, podkreślono współzależność pomiędzy społeczną a ekonomiczną sferą wpływu dziedzictwa kulturowego. Zwrócono uwagę zarówno na rozwój lokalny, przyjmując perspektywę jednostek $\mathrm{i}$ ich indywidualnego stosunku do dziedzictwa, jak i przeanalizowano perspektywę zbiorowości, eksponując rolę dziedzictwa w rozwoju lokalnym i budowaniu więzi [Dziedzictwo..., 2012]. Również w analizach dotyczących gospodarki przyszłości coraz częściej jest podkreślana rola dziedzictwa kulturowego w kształtowaniu się tzw. przemysłów kultury i kreatywnych [Mackiewicz, 2008]. Warto zwrócić uwagę, że w literaturze przedmiotu szczególna rola dostrzegana jest w konsumpcji dóbr i usług dziedzictwa kulturowego - zwłaszcza w promocji miejsca (marketingu terytorialnym), rozwoju turystyki kulturowej oraz rozwoju gospodarczym: tworzeniu nowych miejsc pracy, wzroście przychodów lokalnych przedsiębiorców oraz ogólnym wpływie na wysokość PKB. W przygotowywanych analizach przywoływane są najczęściej liczby dotyczące zabytków i odwiedzających je turystów, wydatków ponoszonych na dziedzictwo (jego ochronę, promocję oraz zysków ze sprzedaży dóbr i usług dziedzictwa) oraz udziału przemysłów dziedzictwa w PKB (mimo trudności w jego dokładnym zdefiniowaniu) [Góral, 2015]. Dane te traktowane są, zresztą słusznie, jako podstawa do uznawania dziedzictwa kulturowego za zasób ważny dla rozwoju lokalnego. Trzeba jednak pamiętać, że mamy również do czynienia z licznymi opracowaniami podkreślającymi rolę dziedzictwa kulturowego w kształtowaniu i/lub wzmacnianiu tożsamości kulturowej i poczucia wspólnoty, jakości życia.

Te dwa obszary, mimo podkreślanych współzależności, wydają się funkcjonować rozłącznie, a wzajemne przepływy między nimi są niewyraźne. Dużo mniej miejsca w literaturze przedmiotu zostało poświęcone procesom, na drodze których dziedzictwo jest tworzone i rozwijane, oraz uczestnikom tychże procesów, czyli tym elementom, które w zasadzie stanowią o istnieniu dziedzictwa kulturowego. Problem ten został poruszony przez Gregory'ego Ashwortha [Ashworth, Graham, Tunbridge, 2007], Petera Howarda, Briana Grahama [Graham, Howard, 2008] i Davida Lowenthala, który mówił, że

oswajając przeszłość, powołujemy się na rolę dziedzictwa dla kształtowania naszej teraźniejszości... Dziedzictwo bowiem wyjaśnia naszą przeszłość i stanowi inspirację dla celów współczesnych... [Lowenthal, 1998, s. 5].

Ważnym głosem w dyskusji jest również zaproponowane przez Simona Thurleya procesowe podejście do dziedzictwa kulturowego. Zwraca się w nim uwagę na ewolucję w wartościowaniu i przypisywaniu ról dziedzictwu, co wynika ze wzrostu jego zrozumienia przez członków danej społeczności lokalnej [Thurley, 2005]. W swojej pracy jednak nie uwzględnia on czynników, które umożliwiają przechodzenie z jednego etapu procesu do kolejnego. Wydaje się to ważne dla 
zrozumienia fenomenu dziedzictwa kulturowego. Dlatego też, na podstawie dostępnej literatury przedmiotu oraz badań własnych autorki, w niniejszym tekście została podjęta próba wielowymiarowego spojrzenia na dziedzictwo kulturowe i uwypuklenia współzależności, które zachodzą pomiędzy poszczególnymi interesariuszami dziedzictwa a jego otoczeniem. Przyjęte podejście do omawianego zjawiska, mające swoje korzenie w teoriach biologii, a zwłaszcza badań środowiska, zostało przez autorkę określone mianem „ekologii dziedzictwa”.

\section{Otoczenie dziedzictwa}

Ekologia, jako jedna $\mathrm{z}$ dyscyplin biologii, proponuje analizę wybranych zjawisk wraz ze środowiskiem, w którym one występują. Przyjęcie podobnej perspektywy podczas prób zrozumienia specyfiki dziedzictwa kulturowego wymaga spojrzenia na ten fenomen $\mathrm{z}$ uwzględnieniem otoczenia dziedzictwa oraz zachodzących w nim interakcji. David Throsby, rozwijając swoją koncepcję kapitału kulturowego, mówił o ekosystemach w kontekście zasobów kultury i dziedzictwa, wskazując na nie jako na istotne elementy infrastruktury wspierającej dynamikę gospodarczą [Throsby, 2012, s. 145]. Próba zrozumienia fenomenu dziedzictwa wymaga refleksji nad złożonością jego otoczenia oraz interakcji w nim zachodzących.

Analiza literatury przedmiotu pozwala na wyodrębnienie czterech różnych aspektów dziedzictwa uwypuklanych podczas refleksji nad tym zasobem, które potraktować można jako podwaliny dla koncepcji ekologii dziedzictwa:

1. interakcje pomiędzy ludźmi a wytarzanymi przez nich artefaktami;

2. podejście procesowe do dziedzictwa;

3. dziedzictwo jako produkt metakulturowy;

4. ujęcie systemowe.

Pierwsze z ujęć odnosi się do interakcji pomiędzy ludźmi a wytwarzanymi przez nich artefaktami, które są reprezentacją danej kultury. Artefakty te mogą przyjmować różne postaci: zabytków nieruchomych i ruchomych, a także formy bardziej złożone, takie jak wytwory rękodzieła ludowego, pieśni, tańce, obrzędy i zwyczaje, będące elementami życia codziennego ludzi. Po raz pierwszy zostały one poddane głębszej refleksji podczas prac nad Konwencjami UNESCO [Konwencja..., 1972]. Interakcje między ludźmi, zarówno tworzącymi, jak i odbiorcami wytworów dziedzictwa, mogą zachodzić w różnych wymiarach: na przykład reprezentować tożsamość indywidualną lub zbiorową określonych społeczności [Smith, 2006], świadczyć o odrębności kulturowej danej grupy społecznej, a także wpływać na rozwój dobrobytu mieszkańców, stanowiąc ich źródło przychodów [Throsby, 2012]. Mogą również dostarczać odbiorcom wrażeń estetycznych i pomóc zrozumieć inne kultury i grupy społeczne. Idealnym przykładem obrazującym złożoność interakcji między ludźmi a artefaktami może być ten obserwowalny podczas uroczystości Niedzieli Palmowej, obchodzonej co roku w małopolskiej Lipnicy Murowanej. Mieszkańcy, zgodnie z lokalnymi zwyczajami, przygotowują ręcznie palmy wielkanocne, które następnie zgłaszane są do konkursu na najwyższą palmę. Konkurs rokrocznie 
przyciąga dziesiątki tysięcy turystów chcących podziwiać arcydzieła sztuki rękodzielniczej lipniczan. Palmy wielkanocne stanowią nie tylko o wyjątkowości kulturowej Lipnicy, ale są też elementem tradycji chrześcijańskiej, a także wiary ludowej (mieszkańcy wierzą, że poświęcone w kościele palmy, umieszczone na polach uprawnych, przyniosą owocne plony i odstraszą złe duchy).

Współczesne podejście do dziedzictwa, co zostało już zasygnalizowane, proponuje również ujęcie go w formie procesowej, pokazując wielość funkcji i obszarów jego oddziaływania na społeczności lokalne. Proces ten, zdaniem Thurleya, ma postać powtarzalnego cyklu istnienia dziedzictwa i rozpoczyna się za każdym razem na nowo wraz z pojawianiem się kolejnych pokoleń społeczności, które muszą na swój własny sposób ustosunkować się do spuścizny przodków, czyli poddać ją reinterpretacji [Thurley, 2005]. W cyklu dziedzictwa można wyodrębnić cztery główne fazy:

1. Zrozumienie dziedzictwa - polega ono na identyfikowaniu obiektów, praktyk, zwyczajów, które dla danej społeczności są ważne. Kiedy elementy te zostaną rozpoznane, członkowie społeczności zaczynają przypisywać im określone wartości kulturowe.

2. Przypisywanie dziedzictwu wartości. Społeczność lokalna zaczyna utożsamiać z obiektami dziedzictwa kulturowego konkretne wartości, m.in. historyczne, estetyczne, a to prowadzi do tego, że dana społeczność zaczyna odczuwać potrzebę opieki nad swoim dziedzictwem kulturowym.

3. Ochrona obiektów dziedzictwa kulturowego. Społeczność lokalna podejmuje działania zmierzające do zachowania swojego dziedzictwa - może to być dbałość o zachowanie ciągłości przekazu (transfer tradycji, praktyk, zwyczajów z pokolenia na pokolenie) i/lub otoczenie go opieką instytucjonalną (działalność muzeów, archiwów, galerii itp.).

4. Czerpanie z dziedzictwa kulturowego radości, przyjemności i korzyści. Jest to ostatnia i najbardziej zaawansowana faza cyklu funkcjonowania dziedzictwa w danej społeczności, w danym pokoleniu. To etap najwyższej świadomości posiadanego bogactwa, w którym społeczność lokalna czerpie korzyści z tego dziedzictwa, czy to w formie rozwoju kulturalnego, społecznego, czy też świadomego rozwoju gospodarczego.

Inne, równie interesujące ujęcie dziedzictwa kulturowego, zwłaszcza tego o charakterze niematerialnym, proponuje Barbara Kirshenblatt-Gimblett w swojej koncepcji metakulturowości. Badaczka określa dziedzictwo kulturowe mianem produktu metakulturowego, zwracając szczególną uwagę na pojęcie czasu i jego roli w tworzeniu dziedzictwa. Podkreśla, że nie jest ono jedynie wytworem przeszłości, czyli czymś w pewnym sensie skończonym, ale jest nieustannie odtwarzane i stale powstaje na nowo, co poniekąd łączy się również z Thurley’owskim spojrzeniem na dziedzictwo. W procesie dziedzictwa, zdaniem Kirshenblatt-Gimblett, operacje służące zachowaniu pamięci i zabytków przeszłości zostają uzupełnione obecnością żywych ludzi, ich wiedzą, praktykami kulturowymi, standardami postępowania, wewnętrznymi regulacjami społeczności, w których funkcjonują, oraz ich przestrzenią życiową [Kirshenblatt-Gimblett, 2004]. Podobnie, prawie dekadę wcześniej, Stewart Hall podkreślał, że 
To ludzie wypełniają rzeczy określonymi wartościami, nadając im w ten sposób znaczenia. Te jednak, wraz z upływem czasu, ewoluują wraz ze zmianą w postrzeganiu otaczającej nas rzeczywistości [Hall, 1997, s. 61].

Złożony charakter dziedzictwa kulturowego uwypukla również fakt, iż z każdym obiektem dziedzictwa jest powiązanych wielu interesariuszy [Gaweł, 2012]. Określają oni sposoby postrzegania dziedzictwa w danej społeczności, które Laurajane Smith określa mianem

autorytarnego dyskursu dziedzictwa, postrzegającego dziedzictwo jako plastyczny, zmienny w czasie konstrukt uzależniony od pozycji społecznej, pochodzenia i biografii podmiotu wypowiadającego się, a także koniunktury politycznej czy momentu historycznego [Smith, 2006].

Inaczej dziedzictwo będzie definiowane przez członków społeczności lokalnej, którzy będą o nim myśleli jako o części swojej tożsamości kulturowej, inaczej przez turystów, którzy chcą w nim widzieć atrakcje warte zobaczenia lub doświadczenia, inaczej przez przedsiębiorców postrzegających je przez pryzmat korzyści ekonomicznych, a jeszcze inaczej przez władze regionalne, poszukujące w nich kontekstów politycznych, które można wykorzystać do zarządzania rozwojem danego terytorium.

Ważnym głosem w dyskusji na temat dziedzictwa kulturowego jest spojrzenie na nie przez pryzmat teorii systemów podczas analizy modeli zarządzania produktami dziedzictwa, co czyni m.in. Łukasz Gaweł, omawiając szlaki kulturowe [Gaweł, 2011]. Sama teoria systemów, która ma swoje korzenie między innymi w biologii, niejako łącząc wspomniane już paradygmaty, podkreśla rolę poszczególnych elementów systemu dziedzictwa: artefaktów, interesariuszy i ich organizacji oraz zachodzących między nimi interakcji. Teoria systemów wydaje się postrzegać zasoby dziedzictwa kulturowego w kategoriach produktów tworzonych celem zaspokojenia potrzeb określonych grup odbiorców dziedzictwa, podkreślając, że system jest ,wyodrębnioną częścią otaczającej nas rzeczywistości” [Krzyżanowski, 1992, s. 166].

Przytoczone koncepcje dotykają niezmiernie ważnych dla zrozumienia fenomenu dziedzictwa kulturowego wątków. Warto podkreślić, że ich dynamika zależy od otoczenia, w którym są zanurzone. Otoczenie to stanowią środowiska społeczno-kulturowe, polityczne i ekonomiczne, które kształtują wyobrażenia ludzi o tym, co dziedzictwem jest, i pozwalają na zrozumienie jego znaczenia dla indywidualnego, a także zbiorowego rozwoju.

Podsumowując: dziedzictwa są konstruowane, koncentrowane, kształtowane i zarządzane przez, i w odpowiedzi na, wymagania płynnej ponowoczesności, w której funkcjonują współczesne społeczności. Jako takie, dziedzictwa są więc otwarte na stałą rewizję i zmianę, jednocześnie będąc źródłem i wynikiem konfliktu społecznego. Poruszone wątki: wielości koncepcji dziedzictwa kulturowego oraz złożoności otoczenia pokazują, że dla zrozumienia istoty tego zjawiska konieczne jest przyjęcie równie kompleksowej perspektywy, uwzględniającej wszystkie podmioty, interakcje między nimi oraz dynamikę ich zmian, a te są podstawą dla rozwoju paradygmatu ekologii dziedzictwa. 


\section{Społeczno-ekonomiczny kontekst dziedzictwa}

Refleksja nad fenomenem dziedzictwa wymaga spojrzenia na nie przez pryzmat pełnionej funkcji w lokalnych społecznościach, na sposoby, w jakich wykorzystywane jest ono (świadomie bądź nie) w formowaniu społecznego i ekonomicznego rozwoju tych społeczności.

Andrzej Tomaszewski zwraca uwagę na dwa zupełnie różne podejścia do koncepcji dziedzictwa kulturowego, mające swoje korzenie w tradycjach religijnych, kulturowych i filozoficznych społeczeństw Zachodu i Wschodu [Tomaszewski, 2013, s. 56]. Są kultury, które przywiązują niewielką wagę do zachowania obiektów materialnych, preferując rozwój kultury niematerialnej i świata duchowego. Przykładem może być Japonia: tu jedno z najważniejszych miejsc shintōizmu, Świątynia w Ise, co dwadzieścia lat jest przebudowywana, przy użyciu takich samych materiałów, odtwarzając wiernie całą konstrukcję i detale. Tradycja ta utrzymuje się od 685 roku. Pod znakiem zapytania stawia to „tradycyjnie” (europejsko) rozumiane wartości historyczne. Podejście takie, którego źródeł można szukać w cyklicznej teorii dziejów, jest charakterystyczne dla cywilizacji orientalnych. Natomiast europejskie podejście do dziedzictwa kulturowego - duża waga przywiązywana do zabytków kultury materialnej - nie znajduje w cywilizacjach dalekowschodnich uzasadnienia, ponieważ dla nich rola konstrukcji architektonicznych sprowadza się jedynie do przechowania wartości duchowych, które są tam kultywowane. Stosunek do zasobów dziedzictwa kulturowego jest również kształtowany na podstawie struktur grup społecznych, do których dziedzictwo to należy. W społecznościach tradycyjnych - charakteryzujących się niewielkim stopniem migracji, wyraźnym przywiązaniem do tradycji i zwyczajów, silnymi więziami międzypokoleniowymi - poziom świadomości dziedzictwa kulturowego, zwłaszcza w kontekście wzmacniania wartości społecznych, jest wysoki. Inaczej będzie się natomiast kształtował w społecznościach ponowoczesnych, w których przywiązanie do miejsca jest niewielkie, więzi międzypokoleniowe słabną, a tradycje i zwyczaje są odsuwane na plan dalszy. Warto również podkreślić, że dziedzictwo kulturowe, poprzez zaspokajanie potrzeb kulturalnych i rekreacyjnych, zapewnianie dobrej estetyki przestrzeni, w tym przestrzeni publicznych i życia codziennego, ma istotny wpływ na kształtowanie jakości życia społeczeństwa [Murzyn-Kupisz, 2010]. Ponadto w dużym stopniu, zwłaszcza w odniesieniu do tak zwanych rdzennych mieszkańców, wpływa na ich samoidentyfikację i samoocenę, poczucie tożsamości i przynależności. Dodatkowo stymuluje łączność międzypokoleniową, dialog społeczny oraz ogólnie budowanie spójności społecznej. Dziedzictwo przesądza często również o wizerunku danego miejsca czy obszaru, jego atrakcyjności i pozytywnym postrzeganiu - zarówno przez turystów, jak i inwestorów. Może też być istotnym elementem marketingu wewnętrznego skierowanego do mieszkańców. Wreszcie może oddziaływać również na ekologiczne uwarunkowania funkcjonowania danego obszaru: umożliwiać i inspirować bardziej zrównoważone gospodarowanie przestrzenią i zapobieganie niekontrolowanej urbanizacji obszarów podmiejskich i wiejskich [Murzyn-Kupisz, 2010]. 
Coraz wyraźniej eksponowanym kontekstem dla dziedzictwa kulturowego jest jego miejsce w gospodarce. Uwaga badaczy koncentruje się przede wszystkim na analizie korzyści, jakie przynosi dziedzictwo kulturowe, i na tym, co jest istotne, zarówno w krótkiej, jak i dalszej perspektywie. Wśród bezpośrednich korzyści można wskazać między innymi dochody powstające dzięki działalności związanej z zachowaniem, udostępnianiem i interpretacją dziedzictwa kulturowego, oraz tzw. efekty mnożnikowe, w tym tworzenie nowych miejsc pracy, przychody i wydatki sektora publicznego oraz wpływ na rozwój przedsiębiorczości w regionie, zwłaszcza tej związanej z turystyką kulturową. Te interakcje pomiędzy dziedzictwem a gospodarką są szczególnie widoczne na dwóch przykładach: w kontekście budowania gospodarki w krajach rozwijających się (np. programu UNTWO i UNESCO w krajach Afryki i Azji Środkowej') i w krajach wysoko rozwiniętych, gdzie nowe formy kreatywnej gospodarki w dużym stopniu bazują na zasobach kultury i dziedzictwa kulturowego, przyczyniając się do rozwoju innowacyjnych produktów [Mackiewicz et al., 2008]. Dodatkowo warto podkreślić potencjał dziedzictwa, który stanowi wsparcie dla budowania gospodarki opartej na wiedzy oraz wykorzystywany jest jako zasób i przestrzeń dla rozwoju edukacji, wpływa na rozwój kapitałów społecznego i kulturowego oraz stymuluje rozwój kreatywności. Zasoby dziedzictwa kulturowego są również inspiracją dla powstawania oryginalnych, wysokiej jakości produktów w ramach sektorów kreatywnych, ale także poza nimi.

Zarówno społeczne, jak i ekonomiczne otoczenie dziedzictwa jest kształtowane pod wpływem decyzji politycznych i budowanych na ich podstawie strategii rozwoju oraz polityk publicznych, które są wynikiem prac administracji publicznej. Jej organizacja, zakres zadań określonych stosownymi przepisami prawa, dostępne instrumenty zarządzania sprawiają, że administracja publiczna jest istotnym interesariuszem dziedzictwa kulturowego, zarówno jako jego nadzorca, jak i sponsor. Poprzez posiadane uprawnienia do planowania rozwoju przestrzennego obszarów, udzielania koncesji i licencji, tworzenia regulacji prawnych związanych $\mathrm{z}$ funkcjonowaniem przedsiębiorstw, monitorowania standardów wymiany handlowej, jakości produktów oraz strategiczną i finansową rolę w zakresie edukacji może stymulować zrównoważony rozwój regionu oparty na posiadanych zasobach niematerialnego dziedzictwa kulturowego, nie tylko w jego społecznym, ale również, co jest obecnie szczególnie istotne, ekonomicznym wymiarze. Za Throsbym można wskazać instrumenty polityczne, które są stosowane w zarządzaniu zasobami dziedzictwa kulturowego:

1. Publiczna własność i zarządzanie instytucjami, placówkami i obiektami dziedzictwa kulturowego.

2. Wsparcie finansowe na utrzymanie i zachowanie ciągłości przekazu dziedzictwa kulturowego.

3. Regulacje ograniczające lub zawężające prywatne działania w zakresie zarządzania zasobami dziedzictwa kulturowego.

${ }^{1}$ Jako przykład mogą posłużyć projekty The Slave Route oraz The Silk Route, mające na celu rozwój turystyki dziedzictwa w krajach Afryki Środkowej oraz Azji Środkowej. 
4. Edukacja i dostarczanie informacji, jako podstawa kształtowania świadomości społecznej na temat dziedzictwa kulturowego i jego roli w życiu społeczności lokalnych [Throsby, 2012].

Wybór właściwych instrumentów oraz zakresu ich wykorzystania jest jednak zależny od stopnia świadomości i rozwoju społeczeństwa, w którym funkcjonuje dana jednostka administracji publicznej. Już pobieżna analiza lokalnych i regionalnych strategii rozwoju pokazuje, na jak różne sposoby jest i może być ono wykorzystywane do rozwoju. Województwo Małopolskie zwraca uwagę w swojej najnowszej strategii Małopolska 2020 na potencjał gospodarczy dziedzictwa, traktując je w kategorii przemysłów czasu wolnego, podczas gdy w województwie lubuskim w podobnym dokumencie autorzy strategii większą uwagę zwracają na rolę dziedzictwa w budowaniu tożsamości lokalnej. Te różne ujęcia znajdują następnie bezpośrednie odzwierciedlenie w praktyce zarządzania zasobami dziedzictwa i wyznaczają kierunki jego rozwoju.

Każde z zasygnalizowanych tu ujęć dziedzictwa dotyka ważnych dla zrozumienia całej koncepcji aspektów, dlatego podjęcie próby ich kompilacji wydaje się ważne dla dalszego rozwoju zarówno samego zasobu, jak i wykorzystujących go społeczności lokalnych.

\section{Pojęcie ekologii dziedzictwa}

Za punkt wyjścia dla zdefiniowania, czym właściwie jest ekologia dziedzictwa, przyjęto teorię ekologii kulturowej, która już od kilku dekad funkcjonuje na gruncie nauk społecznych i humanistycznych. Pojęcie „ekologii kulturowej” zostało użyte po raz pierwszy na gruncie antropologii w latach 50 . XX wieku przez Juliana Stewarda, który potraktował ją w kategoriach metodologii pozwalającej na zrozumienie, w jaki sposób ludzie adaptują się do złożonych i zmiennych środowisk. Swoją teorię oparł on na analizie związku systemów kulturowych ze środowiskiem przyrodniczym, w którym ów system się ulokował [Nowicka, 2014]. Proces adaptacji kultury do warunków ekologicznych badacz uznał za proces twórczy i najbardziej istotny w toku zmian kulturowych i krystalizowania się konkretnego systemu kulturowego.

Z sektorem kultury natomiast ekologia powiązana została dopiero w XXI wieku. W 2004 roku po raz pierwszy John Holden użył metafory ekologii w odniesieniu do sektora kultury [Holden, 2004]. Badacz ten w swoim najnowszym raporcie The Ecology of Culture, opublikowanym na początku 2015 roku, podsumowuje równocześnie niejednoznaczność oraz złożoność koncepcji ekologii kultury, zwracając uwagę na takie jej cechy charakterystyczne, jak: sieciowanie, ewolucyjny charakter, interakcje i współuczestnictwo, ekonomię i wymiar społeczny kultury, twórców i konsumentów kultury [Holden, 2015]. W zakończeniu swoich rozważań przywołuje, najbardziej trafną jego zdaniem, definicję ekologii kultury zaproponowaną przez Ann Markussen, będącą jedną z wiodących współcześnie badaczek tego zagadnienia: 
definiujemy ekologię kultury i sztuki jako złożone współzależności, które kształtują popyt i produkcję dóbr sztuki i oferty kulturalnej [Markussen et al., 2011, s. 79].

Definicja ta w sposób skondensowany ujmuje wszystkie ze wspomnianych przez Holdena atrybutów ekologii kultury. W ujęciu zaproponowanym przez Markussen, przyjmując klasyczną definicję sektora kultury, można oczywiście zmieścić również dziedzictwo kulturowe, które przecież stanowi część ekosystemu kultury. Niemniej ze względu na omówioną wcześniej złożoność zjawiska i kompleksowość jego środowiska, wydaje się, że warto potraktować je odrębnie, eksponując przy tym wyjątkowość zasobów dziedzictwa.

Za punkt wyjścia dla zdefiniowania, czym jest ekologia dziedzictwa, przyjęto zjawisko tzw. stabilności kulturowej, określanej obecnie coraz częściej jako zrównoważony rozwój kulturowy. Koncepcja ta, upowszechniona m.in. w pracach Throsby'ego, Smith, Purchli czy Murzyn-Kupisz, opiera się na zasadzie sprawiedliwości międzypokoleniowej, będącej podstawą zrównoważonego rozwoju. Oczywiście, w kontekście dziedzictwa, można dyskutować nad tezą, że obecne pokolenia mają obowiązek opieki nad posiadanymi dobrami kulturowymi, wynikający z zasady sprawiedliwości międzypokoleniowej i racjonalnego nimi gospodarowania, ponieważ odwołując się do przywołanej już w tym tekście definicji dziedzictwa kulturowego, to przyszłe pokolenia będą decydowały o tym, co za swoje dziedzictwo chcą uznać. Niemniej powinny otrzymać szansę takiego wyboru, którego gwarancją jest zapewnienie przetrwania istniejących zasobów. Ponadto, podobnie jak naturalne ekosystemy są niezbędne do utrzymania działalności gospodarczej, również „ekosystemy” kulturowe oraz różnorodność kulturowa mogą być postrzegane jako istotne elementy infrastruktury wspierającej dynamikę gospodarczą. Ważna w dyskusjach jest również zasada ostrożności, zgodnie z którą zaleca się unikanie ryzykownych decyzji w kwestiach mających potencjalnie nieodwracalne skutki, jak na przykład w kontekście dziedzictwa ginięcie tradycyjnych zawodów. Odniesienie do kapitału kulturowego w tym zakresie jest również istotne, zasada ostrożności powinna być stosowana w kontekście zasobów dziedzictwa kulturowego. Założenia te, w połączeniu z rozważaniami na temat środowiska dziedzictwa, stanowią podstawę dla teorii ekologii dziedzictwa.

Istotne jest jednak, zdaniem autorki niniejszego tekstu, założenie o istnieniu złożonych współzależności pomiędzy trzema podstawowymi filarami dziedzictwa: jego twórcami, producentami i odbiorcami, którzy na wszystkich etapach procesu dziedzictwa kulturowego wchodzą z sobą w interakcje.

Pierwszy filar dziedzictwa stanowią jego twórcy oraz artefakty będące rezultatem ich pracy. Następnie są tzw. producenci dziedzictwa, a tym mianem określa się organizacje (publiczne, prywatne oraz III sektora) odpowiedzialne za tworzenie i wdrażanie założeń polityk sprzyjających ochronie, upowszechnianiu i rozwojowi zasobów dziedzictwa. Ostatni, najbardziej złożony filar stanowią natomiast odbiorcy dziedzictwa (którymi mogą też być jego twórcy i producenci), wchodzący w interakcje z artefaktami będącymi wytworami pracy twórców, zaspokajając w ten sposób swoje różnorakie potrzeby: artystyczne, estetyczne, 
edukacyjne, poznawcze. Relacje zachodzące między poszczególnymi filarami decydują o kształcie i dynamice rozwoju zasobów dziedzictwa kulturowego. Pomiędzy wspomnianymi filarami dziedzictwa występują stałe przepływy wiedzy, idei, pieniędzy i produktów, które nadają kształt i znaczenie poszczególnym artefaktom dziedzictwa.

Przykładowo podtrzymanie i rozwój tradycji koronczarskiej w małopolskiej Bobowej zależy od liczby artystek koronczarek chcących wytwarzać produkty zgodnie z założeniami sztuki oraz liczby przedstawicieli młodego pokolenia chcących nauczyć się sztuki od swoich przodków. Chęć ta jest najczęściej motywowana możliwościami wykorzystania tej sztuki do rozwoju osobistego (ekonomicznego i społecznego), warunkowanego popytem na produkty koronczarskie (liczbą odbiorców zainteresowanych nabyciem produktów koronczarskich). Jednocześnie producenci dziedzictwa mogą tworzyć warunki sprzyjające rozwojowi zainteresowania sztuką koronczarską zarówno wśród twórców (programy wsparcia dla artystów, ulgi podatkowe itp.), jak i odbiorców (działalność muzeów i instytucji kultury prezentujących i promujących sztukę koronczarską, marketing miejsca, otwarte pracownie artystyczne, produkty i usługi oferowane przez przedsiębiorstwa z sektora przemysłów kultury i kreatywnych).

Opisane założenia pozwalają, w opinii autorki, ekologię dziedzictwa definiować następująco:

Złożone, zanurzone w dynamicznym otoczeniu współzależności, które kształtują relacje pomiędzy twórcami, producentami a odbiorcami dziedzictwa.

Co prawda zaproponowane ramy dla ekologii dziedzictwa nie są idealne. Można im zarzucić eksponowanie wartości ekonomicznych: pobyt na produkty/ artefakty dziedzictwa wśród odbiorców, chociaż, co zresztą wielokrotnie było podkreślane przez badaczy dziedzictwa (por. Throsby, Ashworth, Gaweł), nie jest to jedyną wartością dziedzictwa. Ponadto, na co zwrócono już uwagę, trudno nakreślić wyraźną granicę pomiędzy twórcami a producentami i odbiorcami dziedzictwa, gdyż dynamika zachodzących między nimi relacji jest na tyle złożona, że trudno jednoznacznie przypisać poszczególnym organizacjom/osobom konkretne role. Niemniej wydaje się, że umożliwiają one holistyczne spojrzenie na zagadnienie dziedzictwa kulturowego, zwracając uwagę na główne filary dla jego efektywnego wykorzystania w zrównoważonym rozwoju lokalnym.

\section{Wnioski}

Świadomość złożoności opisywanego problemu, zwłaszcza wśród kadry zarządzającej, wyznaczającej kierunki rozwoju lokalnego, pozwala na budowanie efektywnej strategii zarządzania posiadanymi zasobami na podstawie rzeczywistej idei zrównoważonego rozwoju. Jak pisał David Throsby, uwzględniając w modelu zrównoważonego rozwoju nie tylko kwestie ekonomiczne, ale organizując proces 
rozwoju tak, aby obejmował zarówno kwestie gospodarcze, społeczne, kulturowe i ekologiczne, możemy mówić o takim paradygmacie rozwoju, który jest skupiony na człowieku i na pełni jego potrzeb materialnych i niematerialnych [Throsby, 2012, s. 145]. Zarządzanie oparte na tych założeniach nadaje praktyce zarządzania dziedzictwem wyraźne cechy humanizmu. Jednakże nie można zapominać, że dotyczy ono również konkretnych działań i wdrożeń, co wyraża się w osiąganych wynikach, a to sprawia, że zarządzanie można określać też jako technologię [Drucker, 2001, s. 29].

Przedstawione rozważania dotyczące ekologii dziedzictwa skłaniają do głębszej refleksji na temat tego, w jaki sposób dziedzictwem należy zarządzać. Podkreślić trzeba przy tym konieczność dalszych badań, mających na celu znalezienie odpowiedzi na pytania: W jaki sposób tworzone jest dziedzictwo? W jaki sposób jest rozwijane? Jakie zagrożenia mogą pojawić się dla jego rozwoju? Jakie relacje zachodzą pomiędzy dziedzictwem a jego otoczeniem? Refleksja nad odpowiedziami na zasygnalizowanie pytania pozwala odkryć na nowo zjawisko dziedzictwa kulturowego, zwłaszcza w takim zakresie, jak:

1) procesy tworzenia dziedzictwa;

2) rola dziedzictwa w zrównoważonym rozwoju;

3) sieci współpracy i współzależności na rzecz dziedzictwa.

W proponowanym ekologicznym ujęciu omawiany cykl dziedzictwa, opisany przez Thurleya [2005], wydaje się nabierać wyraźniejszych kształtów: uzmysławia badaczom, że większą uwagę należy zwrócić na to, co dzieje się pomiędzy poszczególnymi fazami cyklu dziedzictwa i na sposób, w jaki społeczności lokalne faktycznie kształtują swoje dziedzictwo. Podkreśla to złożoność relacji zachodzących pomiędzy określonymi artefaktami a ich użytkownikami. Wiedza w tym zakresie może służyć usprawnieniu zarządzania dziedzictwem, zwłaszcza w zakresie edukacji na jego temat, pomóc społecznościom lokalnym w odkrywaniu swojej tożsamości, budowaniu więzi, a także wpłynąć na efektywniejsze wykorzystanie zasobów dziedzictwa w budowaniu zrównoważonego rozwoju.

\section{Bibliografia}

Ashworth G., Graham B., Tunbridge J. (2007), Pluralising Pasts: Heritage, Identity and Place in Multicultural Societies, Pluto Press, Londyn.

Drucker P.F. (2001), Myśli przewodnie Druckera, Wydawnictwo MT Biznes, Warszawa.

Dziedzictwo kulturowe w oczach Polaków - raport z badań społecznych (2012), Narodowy Instytut Dziedzictwa, Warszawa.

Gaweł Ł. (2011), Szlaki dziedzictwa kulturowego, Wydawnictwo UJ, Kraków.

Gaweł Ł. (2012), Zarządzanie strategiczne szlakiem dziedzictwa kulturowego w świetle koncepcji stakeholders, „Turystyka Kulturowa”, nr 10, s. 31-40.

Góral A. (2015), Raport „Dostępność i zakres prowadzonych badań statystycznych w obszarze dziedzictwa kulturowego" [w:] Statystyka kultury w Polsce i Europie, Narodowe Centrum Kultury, Warszawa. 
Graham B., Howard P. (2008), Heritage and Identity [dok. elektr.], http://www.lundhumphries. co.uk/pdf/SamplePages/Ashgate_Research_Companion_to_Heritage_and_Identity_Intro.pdf [dostęp: 15.04.2015].

Hall S. (red.) (1997), Representation: Cultural Representations and Signifying Practices, Sage/Open University, Londyn.

Holden J. (2004), Capturing Cultural Value: How Culture has Become a Tool of Government Policy, Demos, Londyn.

Holden J. (2015), The Ecology of Culture [dok. elektr.], http://www.ahrc.ac.uk/News-and-Events/News/Documents/AHRC\%20Ecology\%20of\%20Culture\%20\%28A\%29.pdf [dostęp: 15.04.2015].

Howard P. (2003), Henitage: Management, Interpretation, Identity, Continuum, Londen, New York.

Kirshenblatt-Gimblett B. (2004), Intangible Heritage as Metacultural Production, „Museum International", nr 1-2 (56), s. 52-65.

Konwencja UNESCO w sprawie ochrony światowego dziedzictwa kulturalnego i naturalnego (1972) [dok. elektr.], http://www.unesco.pl/fileadmin/user_upload/pdf/Konwencja_o_ ochronie_swiatowego_dziedzictwa.pdf [dostęp: 15.01.2015].

Krzyżanowski L. (1992), Podstawy nauk o organizacji i zarzadzaniu, Wydawnictwo Naukowe PWN, Warszawa, s. 166.

Lowenthal D. (1998), The Heritage Crusade and the Spoils of History, Cambridge University Press, Cambridge, s. 5.

Mackiewicz M. et al. (2008), Analiza potrzeb i rozwoju przemysłów kreatywnych [dok. elektr.], http://www.mg.gov.pl/files/upload/10147/Analiza\%20potrzeb\%20i\%20rozwoju\%20 przemyslow\%20kreatywnych.pdf [dostęp: 10.04.2015].

Markussen A. et al. (2011), Califiornia's Arts and Cultural Ecology, James Irvine Foundation, San Francisco.

Murzyn-Kupisz M. (2010), Barbarzyńca w ogrodzie? Dziedzictwo kulturowe widziane z perspektywy ekonomii, „Zarządzanie Publiczne”, nr 3(13), s. 19-32.

Nowicka E. (2014), Świat człowieka - świat kultury, Wydawnictwo Naukowe PWN, Warszawa.

Purchla J. (2014), Dziedzictwo kulturowe a kapitat społeczny [w:] A. Rottermund (red.), Dlaczego i jak w nowoczesny sposób chronić dziedzictwo kulturowe, Polski Komitet do spraw UNESCO, Warszawa, s. 21-30.

Smith L. (2006), Uses of Heritage, Routledge, Londyn.

Throsby D. (2012), Ekonomia i kultura, Narodowe Centrum Kultury, Warszawa.

Thurley S. (2005), Into the Future. Our Strategy for 2005-2010, „Conservation Bulletin” [English Heritage], $\mathrm{nr} 49$.

Tomaszewski A. (2013), Ku nowej filozofii dziedzictwa, Międzynarodowe Centrum Kultury, Kraków.

UNESCO Convention for the Safeguarding of Intangible Cultural Heritage (2003) [dok. elektr.], http://www.unesco.org/culture/ich/index.php?pg=00006 [dostęp: 23.04.2015]. 